\title{
Kâdî Mollâ Muhammed el-Hıdırî ve el-Hul'u lâ ez-Zulmu Adlı Risalesi
}

\section{Kâdî Mollâ Muhammed al-Hidirî and of His Risalah Named al-Hul'u lâ az-Zulmu}

\author{
Sadrettin Buğda a,* \\ ${ }^{a}$ Dr. Öğretim Üyesi, Muş Alparslan Üniversitesi, İslami İlimler Fakültesi, Temel İslam Bilimleri Bölümü, İslam Hukuku ABD., Muş/Türkiye. \\ ORCID: 0000-0002-6135-8570
}

\section{MAKALE BİLGİSİ}

Makale Geçmişi

Başvuru tarihi: 1 Kasım 2020

Düzeltme tarihi: 22 Ocak 2021

Kabul tarihi: 1 Şubat 2021

Anahtar Kelimeler:

İslam hukuku,

Aile hukuku, Hul',

Muhâle'a,

Kâdî el-Hıdırî,

\section{A R T ICLE INFO}

\section{Article history:}

Received: November 1, 2020

Received in revised form: January 22, 2021

Accepted: February 1, 2021

\section{Keywords:}

İslamic Law,

Family Law, Hul',

Muhâle'a,

Kâdî el-Hıdırî,
ÖZ

Aile hayatının temelini teşkil eden evlilik, belirli şartlar dâhilinde nikâh akdiyle erkek ve kadının birlikte hayat sürmelerine bir vesiledir. Temeli sevgi ve saygı üzerine kurulan evlilik, bazen yerini kin ve adâvete terk edebilmektedir. İslam, eşler arasında meydana gelen kin ve adâvet nedeniyle onların daha fazla yıpranmamaları için nikâh bağının sona erdirilmesini çeşitli şekillerde meşru kılmıştır. İslam'a göre boşanma çeşitlerinden biri de hul'/muhâle'adır. İslam, kadının evliliği sürdürememesi durumunda hul' yoluyla yani kadının kocaya bir bedel ödemesi ve kocanın da buna razı olması şartıyla kadına eşinden ayrılma hakkı vermiştir. Bu çalışma İslam'da hul'un hükmü ve ödenecek bedeli konu edinen el-Hul'u lâ ez-zülmu adli risalesinin tahkîk ve değerlendirilmesi ile risalenin yazarı olan Kâdî Mollâ Muhammed el-Hıdırî’nin hayatını konu edinmektedir.

\section{Giriş}

İslam, toplumun çekirdeğini oluşturan ve neslin devamlılığını sağlayan aile kurumuna önem vermekte ve

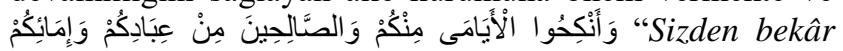
olanlarl, kölelerinizden ve cariyelerinizden durumlarl iyi olanlarl evlendirin" (en-Nûr 24/32) ayetinin gösterdiği gibi evliliği teşvik etmektedir. Nikâh akdi ile tesis edilen evlilik, hem eşler arasında mahremiyet alanı oluşturarak hayatın sağlıklı sürmesinde hem de psikolojik ve sosyolojik huzurun oluşmasında önemli bir faktördür. Ancak sadakat ve hoşgörü esasına dayalı olarak gerçekleştirilen evlilik bazen hayatın çekilmez bir olgusu haline dönüşebilmektedir. İslam, sadakat, hoşgörü, sevgi gibi aile hayatının idamesi için gerekli olan unsurların tükendiği durumlarda boşanma yoluyla eşlerin birbirlerinden ayrılmasını mubah kılmıştır.

İslam hukukunda eşlerin birbirlerinden ayrılmasının farklı şekilleri bulunmaktadır. Bunlardan birincisi tek taraflı irade beyanına dayanan ve talak olarak isimlendirilen boşama çeşididir. Söz konusu boşama çeşidi evliliğin sürdürülebilmesi için yeni bir akde ihtiyaç olup olmaması açısından "ric'î’” ve "bâin”, Sünnet'e uygun olup olmama açısından da "sünnî" ve "bid'î" şeklinde farklı kısımlara ayrılmaktadır. İkincisi ise her iki tarafin da irade beyanına

\footnotetext{
* Sorumlu yazar/Corresponding author.

e-posta: s.bugda@alparslan.edu.tr
} 
dayanan hul'/muhâle'a çeşididir ki bu çeşit boşamada kadının kocaya belli bir bedel verme zorunluluğu da bulunmaktadır. Üçüncüsü ise kazaî boşamadır ki buna tefrîk de denilmektedir. Kazaî boşama/tefrik, kadının, iktidarsızlık gibi belirli hastalıklar, gaiplik hali, şiddetli geçimsizlik ve nafakanın temin edilememesi gibi gerekçelerle mahkemeye başvurması üzerine evliliğin, mahkeme kararıyla sona erdirilmesidir. Kadının haklı gerekçelerle mahkemeden tefrîk talep etmesi durumu üzerine yapılan boşanmada kocanın irade beyanı söz konusu değildir. Zira mezkûr durumlarda da kocanın irade beyânı söz konusu olsaydı kadının mağduriyetinin giderilmesi imkânsız hale gelecekti. Mezkûr boşama çeşitlerinin yanı sıra ilâ, li‘ân ve fesih ile de evlilik akdi sonlandırılabilir. Îlâ, kocanın karısıyla ilişkiye girmeyeceğine dair yemin edip karısıyla cinsi münasebette bulunmayı kendisine yasaklamasıdır (er-Reîs vd., 1439/2017: I/309). Li'ân kocanın hâkim huzurunda karısının zina ettiği veya çocuğun zina ürünü olduğu iddiasında bulunarak bunu yeminle teyit etmesi ve kadının da kocasının yalan söylediğini ve kendisinin mâsum olduğunu söyleyerek aynı şekilde yemin etmesidir (Abdulmun'im, b.s.: III/175). Fesih, nikâhın şahitsiz kıyılması veya evlenen kişilerin daha sonra birbirlerinin mahremi oldukları ortaya çıkması gibi nikâh akdi esnasında veya sonrasinda meydana gelen bir eksiklikten ve yanlışlıktan dolayı evliliğin sona erdirilmesidir (ez-Zuhaylî, 1409/1989: VII/348).

Çalışmaya konu olan el-Hul'u lâ ez-zülmu adlı risalenin muhtevâsı da yukarda zikredilen boşanmanın ikinci çeşidine ilişkindir. Risalede tek bir mezhebin fetvalarına bağlı değil de her dört mezhebe bağlı âlimlerinin fetvaları esas alınarak muhâle'anın yapılmasında ödenecek bedel miktarı konusu geniş bir şekilde incelemeye tabi tutulmuştur.

$\mathrm{Bu}$ çalışma, İslam aile hukukunda önemli bir konu olan muhâle'a meselesini, ilgili kişilere sunmayı ve mezkûr risale vesilesiyle Kâdî Mollâ Muhammed el-Hıdırî’yi de tanıtmayı amaçlamaktadır.

$\mathrm{Bu}$ çalışmanın tahkikli metnin oluşturulmasında İSAM Tahkikli Neşir Esasları benimsenmiştir. Tahkikli metnin tek bir nüsha olması ve başka nüshaların olmaması nedeniyle başka metinlerle karşılaştırma yapılmamıştır. Ancak başka eserlerden yapılan alıntılar asıllarıyla karşılaştırılmış, müellifin "وفي ص 124 ج 4 من şeklinde verdiği cilt ve sayfa numaraları çıkarılmış, kaynakçada verilen basım yeri ve tarihleri esas alınarak dipnotta yeniden cilt ve sayfa numaraları verilmiştir. Metin içinde geçen âyetlerin bulunduğu sûre adları ve âyet numaraları verilmiştir. Hadislerin tahrîci yapılmıştır. Metinde geçen ancak meşhur olmayan kişilerin kısa künyeleri dipnotta verilmiştir. İhtiyaca binaen metne yapılan ilaveler köşeli parantez içinde verilmiştir. Metin içinde geçen kitap isimleri tırnak

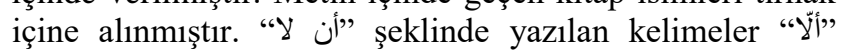
şeklinde yeniden yazılmıştır. "ق لق" "حibi rumuzların açıklamaları dipnotta verilmiştir. Varakların sayfa numaraları, varakların ön yüzü ifade eden " $g$ " harfi ve arka yüzü ifade eden "ظ” harfi ile birlikte eğik çizgi ve akabinde köşeli parantez içinde şu şekilde [ [ 1$]$ / belirtilmiştir.

\section{Hul'/Muhâle'a}

Kâdî Mollâ Muhammed el-Hıdırî’nin hayatını ve eserini ele almadan önce hul'un tanımına ve hükmüne değinmekte yarar vardır. Zira hul'de/muhâle'ada verilecek bedelin neye karşılık olduğunun anlaşılması, muhâle'anın ne olduğu ve onun şer'î hükmünün bilinmesiyle mümkün olmaktadır.

Hul" kelimesi sözlükte "h-l-a" (خلع) fiilinden türeyip “elbiseyi çıkarmak, ayırmak" manalarına gelmektedir (İbn Manzûr, 1996: IV/179). Ebü'l-Hasen el-Mâverdî (ö. 450/1058) hul" kelimesini terim olarak "Bir bedel karşılığında eşlerin birbirlerinden ayrılması” (el-Mâverdî, 1414/1994: X/3) şeklinde tanımlamaktadır. Eşlerin karşılıklı rızalarına bağlı olarak kadının kocasına vereceği bir bedel karşılığında evlilik bağının hul' ve benzeri bir lafiz ile sona erdirilmesi şeklinde de tanımlanabilir. Zira hul'un geçerli olması için eşlerin rızası, kocaya bir bedelin verilmesi, kocanın da muhâle‘a yoluyla ayrılmayı kabul ettiğine dair hul' vb. bir lafizla irade beyanında bulunması gereklidir.

Hanefilere göre muhâle'anın gerçekleşmesi için yapılan irade beyanı hul' lafzıyla yapılabileceği gibi mübâree, müfâraka bey'-şirâ ve talâk ile de yapılabilir. Ancak Hanefiler muhâle'a kastıyla talâk lafzı bir bedelle birlikte kullanılması gerektiğini ifade etmişlerdir (el-Haskefî, 1423/202: 234; Zuhaylî, 1409/1989: VII/482-483). Mâlikîler ise muhâle'ada irade beyanının hul', mübâree, sulh ve fidye lafizlarıyla yapılabileceğini belirtmişlerdir (İbn Rüşd, 1408/1988: II/66). Şâfiîler ve Hanbelîler, irade beyanı hul' ve mufâdât lafzı ile yapılabileceği gibi talâk ve talâka kinaye olan lafizlarla da gerçekleşebileceğini söylemişlerdir (Mâverdî, 1414/1994: X/9; İbn Kudâme 1412/1992: X/275-276).

\section{Muhâle'anın Meşruiyeti}

Evlilikte aslolan, eşlerin karşılıklı sevgi, saygı ve sadâkat içinde olmaları, iki taraftan da kaynaklanan kusurların affedilmesi ve evliliğin bir ömür boyu devam ettirilmesidir (el-Hinn vd., 1413/1992: IV/120). Bundan dolayıdır ki İslâm, mut'a nikâhı gibi süreli birlikteliğe dayalı nikâh akitlerini reddetmiş ve bu şekilde yapılan nikâhı haram olarak nitelendirmiştir. Ayrıca İslam'ın arzuladığı evliliğin bir ömür boyu devam etmesi gerekliliğinin göstergelerinden biri de eşler arasındaki anlaşmazlık nedeniyle hemen boşanmayı değil belki bunu üç aşamalı olarak tavsiye etmesidir (el-Hinn vd., 1413/1992: IV/133). Bunun da en

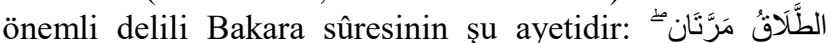
"Boşama iki defadır. Bundan sonrası ya iyilikle tutmak ya da güzellikle salıvermektir" (elBakara 2/229). Boşanmanın üç aşamalı olarak tavsiye edilmesinde güdülen amaç ise eşlerin pişman olup tekrar birlikte yaşamak istemeleri durumunda bunan imkân tanımasıdır. Ancak evlilikte esas olan huzurlu bir şekilde birlikte yaşama hayatı, bazen sürdürülemez bir seviyeye varılabilir. Sevgi ve sadâkat üzerine kurulan aile hayatı yerini üzüntüye, sıkıntıya, psikolojik veya fiziksel işkenceye birakabilir. Söz konusu durumlara binaen İslam hukuku, hayatın çekilmezliğini ortadan kaldırılması, ayrılan eşlerin yeni ve mutlu bir hayat yaşamaları için eşlere ayrılma hürriyetini vermiştir.

Yukarıda da geçtiği gibi İslâm hukukuna göre talâk, ilâ, li’ân, fesih, tefrîk gibi birçok şekilde evlilik sona 
erdirilebilir. Hul`/muhâle‘a da bunlardan biridir. İslâm hukukuna göre hul'un meşruiyeti Kur'ân'a, sünnete ve icmâ‘a dayanmaktadır (Mâverdî, 1414/1994: X/4-5; İbn Rüşd, 1408/1988: II/67; İbn Kudâme, 1412/1992b: X/267; en-Nevevî, ts.: V/681; İbn Hümâm, 1415/1995: IV/188).

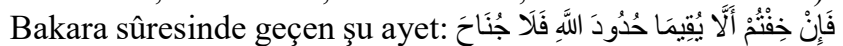

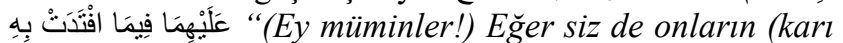
ile kocanın), Allah'ın sinırlarını hakkıyla muhafaza etmeyecekler diye endişe ederseniz, (o zaman) kadının (boşamak için kocasına) fidye vermesinde her iki taraf için de günah yoktur" (el-Bakara 2/229) muhâle'anın temel dayanağıdır. Mezkûr ayette geçen "kadının fidye vermesinde..." şeklindeki pasaj, muhâle'anın kadının bir bedel vermesiyle mümkün olduğunu ortaya koymaktadır. Şu hadis de muhâle'anın dayanağını teşkil etmektedir: Sabit b. Kays'1n karısı Peygamber'e (s.a.v.) gelerek: 'Ey Allah'ın Resûlü! Sabit b. Kays'ı ahlak ve din hususunda ayıplamıyorum, fakat Müslümanlıkta küfürden (küfrân-ı nimetten) çekiniyorum" dedi. (Bunun üzerine) Resûlullah (s.a.v.) "Onun (Kays’ın) bahçesini geri verecek misin?" diye sorunca (Kays'ın karisı) "Evet" diye cevap verdi. (Bunun üzerine) Resûlullah (s.a.v.), (Sabit'e) "Bahçeyi kabul et ve onu bir defa boşa" buyurdular. (Buhârî, Nikâh, 1422: 2; İbn Mâce, Talak, 1430/2009: 22; Nesâî, Talak, 1406/1986: 34). Söz konusu ayet ve hadiste her ne kadar bedel veren kişinin kadın olsa da başka bir ifadeyle özne konumunda olan kişi kadın olsa da muhâle'anın gerçekleşebilmesi için kocanın irade beyanında bulunması zorunludur. Dolayısıyla şunu söylemek mümkündür: Evliliğin sona ermesi için talâkta sadece kocanın irade beyanında bulunması yeterliyken muhâle'ada her iki eşin de irade beyanında bulunmaları zorunludur.

Muhâle'anın meşru oluşuna delâlet eden diğer bir delil de icmâ'dır. İslâm ulemâsı muhâle'anın meşrûiyeti hususunda icmâ' etmişlerdir. Ancak Ebû Bekr b. Abdullah el-Müzenî

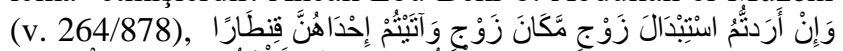

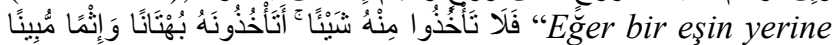
başka bir eş almak isterseniz onlardan birine bir yük altın vermiş olsanız bile ondan hiçbir şey almayın. Siz iftira ederek ve apaçık günah işleyerek onu (verdiğiniz malı) geri alacak misınız?" (en-Nisâ 4/20) ayetini ileri sürerek muhâle'aya delâlet eden ayetin mansûh olduğunu iddia ederek kocanın karısından herhangi bir şey almasının helal olmadığını söyleyerek icmâ'a muhalefet etmiştir (Mâverdî, 1414/1994: X/5; İbn Kudâme, 1412/1992: X/267). Ancak onun ileri sürdüğü görüşün icmâ'a bir etkisi olmadığını söylemek mümkündür. Zira ondan önce sahabe, hul meselesinde icmâ' etmiştir (Mâverdî, 1414/1994: X/5). F1kıh usulüne göre icmâ' hasıl olduktan sonra icmâ'a muhalif olarak ileri sürülen görüşlerin, geçekleşmiş icmâ'a bir etkisi olamaz ve ileri sürülen görüş şaz olarak değerlendirilir (Cessâs, 1985: III/310; ez-Zerkeşî, 1414/1994: VI/514).

\section{Hul'un/Muhâle'anın Hükmü}

Yukarıda geçen ayet ve hadisten de anlaşıldığı gibi muhâle'a, keyfilik esasına değil ancak geçimsizlik gibi haklı bir sebebe binaen başvurulması gereken bir durumdur. Haklı bir gerekçe olmadan muhâle'anın geçerliliği hususu ise âlimler arasında tartışma konusu olmuştur. Cumhûr,

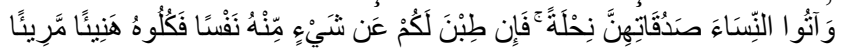
"Kadınlara mehirlerini gönül rizası ile verin. Ĕger kendi istekleriyle o mehrin bir kısmını size bağışlarlarsa, onu da afiyetle yiyin" (en-Nisâ 4/4) ayetini delil getirerek huzursuzluk veren herhangi bir neden olmadığı halde yapılan hul' işlemi İslâm hukuku açısından geçerli olduğu söylemişlerdir (Mâverdî, 1414/1994: X/7). Fakat herhangi ârızî bir neden olmadıkça dinen sürdürülmesi istenilen evliliğin gereksiz bir şekilde bozulması cumhûr tarafından mekruh görülmüştür (İbn Rüşd, 1408/1988: II/68; İbn Kudâme, 1412/1992: X/270-271). Cumhûr, "Herhangi bir kadın, kabul edilebilir bir neden olmaksızın kocasından ayrlmak istiyorsa cennetin kokusu ona haram olur" (Ebû Dâvûd, Talâk, ts.: 18) hadisini gerekçe göstererek eşlerin verilen hakkı istenilen amacın dışında kullandıkları için günah işlemiş olduklarını ifade etmişlerdir (Atar, 2005: XXX/400). Nahaî (ö. 96/714), Atâ (ö. 114/732), Zührî (ö. 124/742), Ahmed b. Hanbel (ö. 241/855), Dâvûd ez-Zâhirî

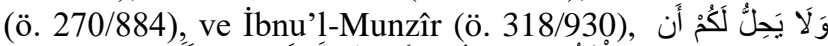

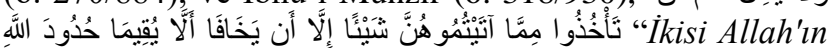
yasalarını koruyamamaktan korkmadıkça kadınlara verdiklerinizden (mehirden) bir şey almanız size helal değildir." (el-Bakara 2/229) ayetine dayanarak haklı bir gerekçe olmadan eşlerin muhâle'aya başvurmaları haram olduğunu belirtmişlerdir. Onlar, yapılan hul'un batıl olduğunu ve alınan malın da kadına iade edilmesi gerektiğini ifade etmişlerdir (Mâverdî, 1414/1994: X/7; İbn Rüşd, 1408/1988: II/68; İbn Kudâme, 1412/1992: X/271; Zuhaylî, 1409/1989: VII/484). Ebû K1lâbe (ö. 104/722) ve Hasan el-Basrî’ye (ö. 110/728) göre ise koca, karısının zina yaptığını görmeyinceye kadar hul' câiz değildir (İbn Rüşd, 1408/1988: II/68; İbn Kudâme, 1412/1992: X/271). Ebû Bekr b. Abdullah el-Müzenî'ye göre ise hul' mutlak anlamda câiz değildir. Yukarıda da geçtiği gibi o muhâle'aya delâlet eden ayetin mansûh olduğunu, karı ve koca ancak talak veya zihâr gibi ayrılmanın diğer şekliyle evlilik bağlarını sona erdirebileceklerini belirtmektedir (İbn Rüşd, 1408/1988: II/67; İbn Kudâme, 1412/1992: X/271).

Baskı ve tehdit altında yapılan muhâle'anın geçerli sayılıp sayılmayacağı konusu da âlimler arasında tartışma konusu

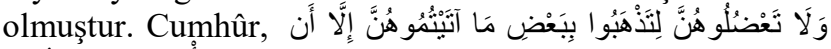
“'Apaçık bir hayâsızlık yapmadıkça onlara verdiğinizin (mehrin) bir kısmını geri almak için onları sıkıştırmayın" (en-Nisâ, 4/19) ayetini delil getirerek kocanın verdiği mehri geri almak için eşini muhâle'aya zorlamasını caiz görmemiş, baskı altında yapılan muhâle'ayı da geçersiz saymış ve verilen malın iade edilmesi gerektiğini belirtmişlerdir (Mâverdî, 1414/1994: X/6; İbn Kudâme, 1412/1992: X/272). Hanefî âlimleri ise yapılan akdin sahih ve bedelin verilmesinin de gerekli olduğunu ifade etmişleridir (es-Serahsî, 1414/1993: VI/183; İbn Kudâme, 1412/1992: X/272).

\section{Kâdî Mollâ Muhammed el-Hıdırî: Hayatı, İlmî Kariyeri ve Eserleri}

Mollâ Muhammed el-Hıdırî'nin tam künyesi, el-Allâme elKâdî Muhammed b. Mollâ Abdulazîz b. Hâci Halife Mollâ el-Hıdırî'dir. Kâdî Mollâ Muhammed 1322/1904'te İran'ın Batı Azerbaycan'a bağlı Uşneviye şehrinin Nerziveh köyünde dünyaya gelmiştir. Kâdî Mollâ Muhammed, ilim ile şöhret bulan bir aileye mensup olup daha altı yaşında iken Kur'ân-1 Kerîm'i hatmederek akabinde Farsça okuma ve yazmayı öğrenir. O, sekiz yaşında iken Arapça sarf, nahiv kitaplarını okumaya başlar. Rusya'nın Uşneviye'yi işgal etmesinden sonra Kâdî Mollâ Muhammed ailesiyle birlikte yaklaşık beş yıl memleketinden uzak kalır ve 
eğitimine ara verir. O, Rusya'nın Uşneviye'yi terk etmesiyle birlikte ailesiyle beraber tekrar memleketine döner ve yeniden eğitimine devam eder. Kâdî Mollâ Muhammed bölge âlimlerinden sarf, nahiv, belâgat, mantık, münâzara, tefsir, hadis, kırâat, fikıh, fikıh usûlü, ferâiz, arûz, astronomi, astroloji, geometri gibi birçok alanda ders alır. O, 1348/1929 yılında icâze alarak köyüne döner. Kâdî Mollâ Muhammed köye döndükten sonra yaklaşık beş yıl öğrencilere ders verir, akabinde Uşneviye'nin önde gelenlerin isteği üzerine Uşneviye camisine imâm ve hatip olarak göreve başlar ve orada da ders vermeye devam eder (Eşit, 2019: 28-32; Hidırî, http://oshnevih.blogfa.com/post/4).

Kâdî Mollâ Muhammed el-Hıdırî, yetmiş yıl boyunca ders verdiğini ve bu süre zarfinda tefsir, hadis, fikıh, fikıh usûlü, kelâm, tasavvuf, 'ulûmu'l-Kur'ân, belâgat, münâzara/cedel, tarih, bibliyografya gibi birçok farklı alanda yüz on iki eser kaleme aldığını belirtmektedir. Kâdî'nin bu kadar eser telif etmesi onun ilmî kariyerinin bir göstergesidir. Kâdî Mollâ Muhammed el-Hıdırî'nin birçok alanda eser ortaya koyması, onun "el-Allâme" unvanını almaya vesile olmuştur. O, İran'ın resmi mezhebi şiîlik olması nedeniyle resmi olarak kâdılık görevi yapmamıştır. Ancak yaşadığ1 bölgenin sünnî olması hasebiyle yöredeki şer'î meselelere baktığı için kendisine kâdılık unvanı verilmiştir (Eşit, 2019: 28-32).

İfade edildiği gibi Kâdî birçok eser kaleme almıştır. Bunlardan bazısı şunlardır: 1. el-Fetâva'l-Muhammdeiyye ”. Söz konusu eser soru cevap tarzında ele alınmıştır. Eser yaklaşık dört yüz sayfadan oluşmaktadır. 2. el-Men 'u 'ani’l-mut'ati 'ala'l-mezâhibi'l-arba'a " المنع عن

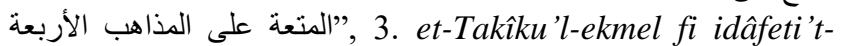

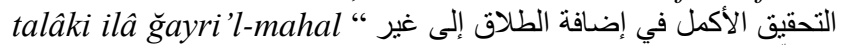

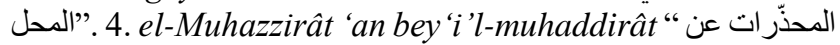
"بيع المخدّرات", 5. Tezvîcu's-siğâr "تزويج الصغار", 6. Ihtirâmi

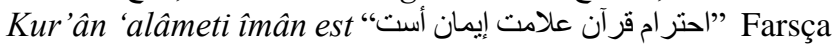
yazdığı bir eserdir. 7. Ve davu'l-mesâbîh fi asli't-terâvîh "وضوء المصابيح في أصل التراويح". Kâdî Mollâ Muhammed, mezkûr eserlerle birlikte fikıh alanında yaklaşık kırk eser telif etmiştir. O, fikıh usûlü alanında da kaleme aldığı eserlerden bazısı şunlardır: 1. el-İrşâd fi ma 'rifeti't-taklîdi ve’l-ictihâd "الإرشاد في معرفة التقليد والاجتهاد", 2. et-Tenkîd

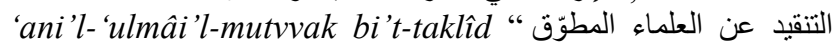
“بالتقليد”. Kâdî’nin kelâm ve tasavvuf alanında telif ettiği bazı eserler şunlardır: 1. Ibtâlu't-ta 'ni ve'r-rac'a " إبطال الطعن

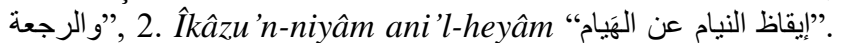
3. Vahdetu'l-vcûd "وحدة الوجود", 4. et-Tesennün ve't-tasavvuf “"التسنن والتصوف", 5. el-Kerâmetu fî nazeri'l-Kur'âni ve'lHadisi ve’t-Tasavvuf “الكرامة في نظر القرآن والحديث والتصوف" Kâdî Mollâ Muhammed tefsir alanında da birçok eser kaleme almıştır. Onun bu konuda kaleme aldığ bazısı şunlardır: 1. el-Emsâlu'l-Kur'âniyye "الأمثال القرآنية"', 2. Tefsiru sûreti yûsuf “تفسير سورة يوسف', 3. Cevâhirü'l-

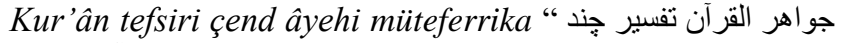

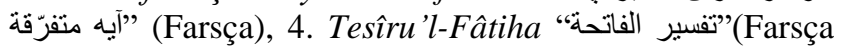
olarak telif edilmiş bir eserdir). Müellifin diğer alanlarda

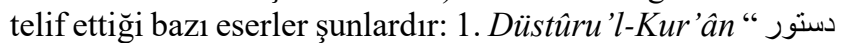

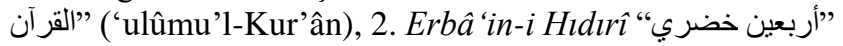
(hadis), 3. Tercemehi tecvîd-i Kur'ân bih zebâni Kurdî "ترجمه تجويد قرآن به زبان كردي" (tecvit). 4. Tarîh-i meşâhîr

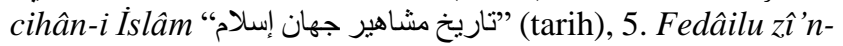
Nûreyn Osmân radiyellahu 'anh " فضائل ذي النورين عثمان رضي الله عنه (bibliyografya), 6. Hâşiyehi müdevveneh ber Saçâklî
Zâde "حاثيه مدونه بر سجاقلي زاده" (münâzara/cedel) (Eşit, 2019: 37-42). Kâdî, ayrica hayat hikâyesini de bizzat kendisi kaleme almaktadır. Yusuf Eşit Kâdî’nin ele aldığı hayat hikâyesini el-Allâme el-Kâdî Mollâ Muhammed Hıdırî ve Risâletuhu et'Talâku's-selâs adlı çalışmasının ilk bölümünde olduğu gibi aktarmaktadır (Eşit, 2019: 29-33).

Bir ömür boyu tedrisât, telifât ve hizmete kendini adayan el'Allâme el-Kâdî Mollâ Muhammed el-Hıdırî' 26 Mayıs 1997 Pazar günü vefat etmiştir (Eşit, 2019: 33).

\section{Kâdî Mollâ Muhammed el-Hıdırî’nin el-Hul'u lâ ez-zülmu Adlı Risalesi}

\section{1. el-Hul'u lâ ez-Zülmu Adlı Risalenin Müellife} Aidiyeti

Kâdî Mollâ Muhammed el-Hıdırî'nin kaleme aldığı hayat biyografisinde bu eserin kendisine aidiyeti kaydedilmektedir. Yusuf Eşit (2019) de el-Kâdî Mollâ Muhammed Hıdırî ve Risâletuhu et'Talâku's-selâs adlı eserinde bu eserin müellife ait olduğunu belirtmektedir. Ayrıca tahkîk konusu olan bu risalenin son varakında müellifin ismi ve memleketinin bulunması da bu risalenin müellife aidiyetini göstermektedir.

\subsection{Risalenin Telif Sebebi ve Tarihi}

Kâdî Mollâ Muhammed el-Hıdırî, el-Hul 'u lâ ez-Zülmu adlı risalenin telif sebebini şu şekilde açıklamaktadır: "Allah'u Teâlâ من التبعيضية "min-i tabîdiyye” ('bir kısmı', 'bazısı' ifade eden 'min') lafzı ile (kadının) rızası olmadıkça kocanın kendisine (kadına) verdiğinden fazlasını geri almasından nehy ettiği halde, Peygamber (s.a.v.) de açık bir şekilde "Amma fazlası (mehirden fazlasının verilmesi) hayır" dediği halde birçok âlimin eşler arasındaki hul" sığasını mehirden ve kocanın kadına verdiğinden fazlasına telkin etiklerini gördüm. (Mezkûr nedenden dolayı) mehirden daha fazlasını almanın helal olmadığına dair Kur'ân ayetlerinden hadislerden ve fakihlerin fetvalarından delil getirerek beyan etmek istedim." Müellifin açık bir şekilde dile getirdiği gibi bazı âlimlerin boşanma karşılı̆̆ında verilen bedelin mehir miktarından daha fazla olabileceği fetvaları, onu bu risaleyi yazmaya sevk etmiştir.

\section{3. el-Hul'u lâ ez-Zülmu Adlı Risalenin İçeriği}

Kâdî Mollâ Muhammed el-Hıdırî, el-Hul 'u lâ ez-zülmu adlı eserinde esas itibariyle kadının evlilik bağını sona erdirmek için kocasından muhâle'a talebinde bulunduğunda ve kocanın da bunun bir bedel karşılığında kabul ettiği takdirde azami olarak koca ne kadar bedel talep edebilir mevzusunu konu edinmektedir. Ayrica o, hangi durumlarda bedelin alınması caiz olduğunu, hangi durumlarda ise caiz olmadığını da risalede ele almaktadır. Müellif bunun yanı sıra muhâle'aya başvurmanın nedenine bağlı olarak hul'un sahih ve batıl yönlerini de irdelemektedir. Müellif mezkûr konuları ele aldıktan sonra aynı mesele çerçevesinde küçük yaşta olan kızların muhâle'a hususundaki durumunu da ele almakta ve buna müteakiben kısa bir sonuç yazmaktadır.

\section{4. el-Hul'u lâ ez-Zülmu Adlı Risalenin Kaynakları}

Kâdî Mollâ Muhammed Hidırî, ele aldığı konu fikhî bir mesele olması hasebiyle başta fikıh kitapları kaynak olarak 
ele almıştır. O, eserinde klasik eserlerin yanı sıra modern eserleri de kaynakça olarak kullanmıştır. Müellif konuyu farklı görüş ve mezhepler çerçevesinde ele alması nedeniyle her mezhebe ait en az bir esere müracaat etmiştir. Müellif ayrıca çağdaş bazı tefsîr kitapları da kaynak olarak kullanmıştır. Onun kaynak olarak kullandığ kronolojik olarak İmâm Mâlik'in (öl. 179/795) elMudevenetu'l-kubrâ, İmâm Şâfîînnin (öl. 204/820) el-Ümm, Bekr er-Râzî el-Cessâs'ın (öl. 370/981) Ahkâmu'l-Kur'ân, İbn Kudâme'nin (öl. 620/1223) el-Muğnî, İbn Teymiyye'nin (öl. 728/1328) el-Fetâva'l-kubrâ, Şihâbüddîn el-Kastallânî'nin (öl. 923/1517) Irşâadu's-sârî li Sahîhi'l-Buhârî, Alâuddîn Haskefî'nin (öl. 1088/1677) edDürrü'l-muhtâr şerhu Tenvîri'l-ebsâr ve câmi'i'l-bihâr, Şevkânî'nin (öl. 1250/1834) Neylu'l-evtâr min ahâdîsi Seyyidi'l-ahyâr, Reşîd Rıâ (öl. 1935), Tefsîru'l-Kur'âni'lhakîm (Tefsîru'l-menâr), Tantâvî'nin (öl. 1940) el-Cevâhir fì tefsîri'l-Kur'âni'l-Kerîm, Abdurrahmân Cezîrî'nin (öl. 1941) el-Fikhu 'ala'l-mezâhibi'l-arba'a ve Seyyid Kutub'un (öl. 1966), Fî zilâli'l-Kur'ân' adlı eserleri şeklinde sıralanabilir.

\section{Sonuç}

Geçimsizlik nedeniyle kadının bir bedel ödeme karşılığında kocasından ayrılmak istemesi neticesinde eşlerin karşılıklı rıza ile ayrılmasını ifade eden hul'/muhâle'a, İslam'ın meşru gördüğü ayrılma çeşitlerinden biridir. İslam, geçimsizlik nedeni olmadan muhâle'aya başvurulmasını doğru bulmamaktadır. Bununla birlikte fakihlerin çoğuna göre herhangi bir nüşûz söz konusu olmadığı halde yapılan muhâle'a hukukî olarak geçerli sayılmaktadır.

İslâm hukukuna göre kadından kaynaklanmayan nüşûz, muhâle'a için gerekçe sayılmamaktadır. Fakihlerin büyük çoğunluğuna göre tehdit ve baskı altında yapılan muhâle'a da hukuken geçersizdir.

Kâdî Mollâ Muhammed el-Hıdırî, el-Hul 'u lâ ez-zülmu adlı eserinde muhâle'a konusunu bütün ayrıntılarıyla ele almasa da muhâle'anın hangi durumlarda sahih ve caiz olduğunu, hangi durumlarda batıl olduğunu, kadın tarafından verilecek bedelin azami miktarını ve buluğ çağına girmemiş kızlar ile yapılan hul'un caiz olup olmadığını geniş bir şekilde ele almaktadır. Müellif muhâle'anın temelde iki eşin rızasına bağlı olduğunu, baskı ve tehdit altında yapılan muhâle'anın batıl olduğunu ifade etmektedir. Dolayısıyla müellif, bu hususta cumhûrun görüşünü benimsemektedir. O, hul ‘ bedelinin mehir miktarından fazla olamayacağını düşünmekte, mehir miktarından fazlasının kadınların haklarının çiğnenmesi anlamına geleceğini iddia etmektedir. Müiellif, buluğ çağına varmayan kız çocuklar ile yapılan muhâle'anın sahih olmadığını belirtmekte, ancak mümeyyiz olması durumunda bedel olmaksızın talakın vuku bulabileceğini ifade etmektedir.

\section{Kaynakça}

Abdulmun'im, M. (t.y.). Mu'cemu'l-mustalahat ve'l-elfâz. el-fikhiyye III. yy.: Dâru'l-Fadile.

Atar, F. (2005). "Muhâle“a" Türkiye Diyanet Vakfi İslâm Ansiklopedisi 30/399-402. Ankara: TDV Yayınlar1.
el-Bağdâdî, U. (1416/1995). el-Lubâb fi 'ileli'l-binâi ve'li 'râb II. Dimaşk: Dâru'l-Fikr.

Beyhakî, E. (1424/2003). es-Sünenü'l-kubrâ X. Beyrut: Dâru'l-Kutubi'l-'İlmiyye.

Buhârî, E. (1422). Câmi 'u's-Sahîh (Sahîhu'l-Buhârî) VIII. yy.: Dâru'n-Necât.

Cessâs, A. (1415/1994a). Ahkâmu'l-Kur'ân. Beyrut: Dâru Kutubi'l-'İlmiyye.

Cessâs, E. (1985b). el-Fusûl fi'l-usûl IV. Kuveyt: Vizâretu'l-Evkâf.

Cezîrî, A. (1424/2003). el-Fikhu 'ala'l-mezâhibi'l-arba 'a $V$. Beyrut: Dâru Kutubi'l-'İlmiyye.

Dârekutnî, E. (1424/2004). Sünenü'd-Dârekutnî V. Beyrut: Müessesetu'r-Risâle,

Ebû Dâvûd, S. (t.y.). es-Sünen (Sünenü Ebî Dâvûd) $I V$. Beyrut: Dâru el-Kitâbi'-Arabî.

Eşit, Y. (2019) el-Allâme el-Kâdî Mollâ Muhammed Hidırî ve Risâletuhu et'Talâku's-selâs. Beyrut: Dâru Kutubi'l'İlmiyye.

Haskefî, A. (1423/2002) ed-Dürrü'l-muhtâr şerhu Tenvîri'l-ebsâr ve câmi'i'l-bihâr, Beyrut: Dâru'lKutubi'l-'İlmiyye.

Hıdırî, Ş. Hatırati Allâme Kâdî Hıdırî, http://oshnevih.blogfa.com/post/4

Hinn, M. vd., (1413/1492). el-Flkhu'l-menhecî 'alâ mezhebi'l-İmâm 'ş-Şâfi î III/VII, Dimaşk: Dâru'lKalem.

İbnü'l-Hümâm, K. (1415/1995). Şerhu Fethi'l-kadîr X. Beyrut: Dâru'l-Kutubi'l-'İlmiyye.

İbn Kudâme, E. (1412/1992). el-Muğnî XV. Kahire: Hecr li't-Tibâ'a ve'n-Neşr ve't-Tevzî‘ ve'l-İ'lân.

İbn Mâce, E. (1430/2009). es-Sünen (Sünenü İbn Mâce) V. Beyrut: Dâru'r-Risâle el-'Alemiyye.

İbn Manzûr, M. (1996). Lisânu’l- 'Arab XVIII. Beyrut: Dâru İhyâi’t-Türâsi'l-'Arabî ve Müessestu't-Târîhi'l-'Arabî.

İbn Rüşd, E. (1408/1988). Bidâyetu'l-muctehid II. Beyrut: Dâru'l-Kutubi'l-'İlmiyye.

İbn Teymiyye, E. (1408/1987). el-Fetâva'l-kubrâ VII. Beyrut: Dâru'l-Kutubi'l-'İlmiyye.

Kastallânî, E. (1323). İrşâdu's-sârî li Sahîhi'l-Buhârî. Misir: el-Matbatu'l-Kubrâ el-Emiriyye.

Mâlik b. E. (t.y.) el-Mudevenetu'l-kubrâ IV. Beyrut: Dâru'1Kutubi'l-'İlmiyye.

Mâverdî, A. (1414/1994) el-Hâvi'l-kebîr XVIII. Beyrut: Dâru'l-Kutubi'l-'İlmiyye.

Nesâî, E. (1406/1986). es-Sünen (el-Muctbâ mine's-Sünen) VIII. Halep: Mektebetu'l-Matbû'âti'l-İslâmiyye.

Nevevî, E. (1425/2005a). Minhâcu't-tâlibîn ve 'umdetu'lmuftîn. yy.: Dâru'l-Fikr.

Nevevî, E. (t.y.). Ravdatu't-tâlibîn VIII. Dâru Kutubi'l'İlmiyye. 
Reîs, İ. vd. (1439/2017). Mu'cemu mustalahât el- 'ulûm eşşer'iyye $I V$. yy.: Medînetu el-Melik Abdulazîz li’l'Ulûmi ve't-Takniyye.

Reşîd Rızâ, M. (1420/1999). Tefsîru'l-Kur'âni'l-Hakîm (Tefsîru'l-menâr) XII. Beyrut: Dâru Kutubi'l-'İlmiyye.

Serahsî, M. (1414/1993). el-Mebsût. Beyrut: Dâru'lMa'rife.

Seyyid Kutup, S. (t.y.) Fî Zilâli'l-Kur'ân VI. Kâhire: Dâru'd-Dimşk.

Şâfîi, M. (1403/1983). el-Ümm VIII. Beyrut: Dâru'l-Fikr.

Şevkânî, E. (1413/1993). Neylu'l-evtâr min ahâdîsi Seyyidi'l-ahyâr VIII. Misır: Dâru'l-Hadîs.
Tantâvî b. C. (1350). el-Cevâhir fì tefsîri'l-Kur'âni'l-Kerîm $X X V$. Misır: Mustafâ el-Bâbî el-Halebî.

Zehebî, Ş. (1414/1994). Siyeru A'lâmi’n-Nubelâ XV. Beyrut: Müessesetu'r-Risâle.

Zerkeşî, B. (1414/1994). el-Bahru'l-muhît fì usûli'l-fikh. 8 Cilt. yy.: Dâru'l-Kutubî.

Ziriklî, H. (2002). el-A 'lâm VIII. Beyrut: Dâru'l-'İlim li’1Melâyîn.

Zuhaylî, V. (1409/1989). el-Fıkhu'l-İslâmî ve edilletuhu VIII. Dımaşk: Dâru'l-Fikr. 
أو قامت عليه بيّنة، ردّ ما أخذ منها عليها. وإن كان طلّقها عليه، لزمه ما سمَّى من عدد الطلاق،

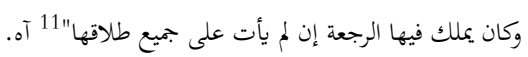

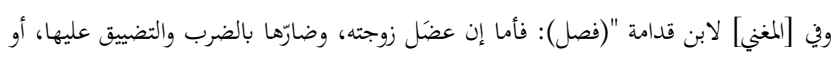

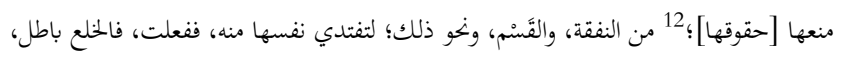

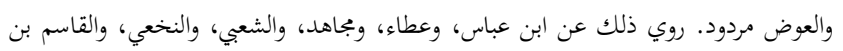

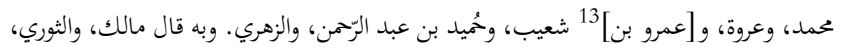

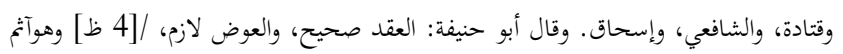

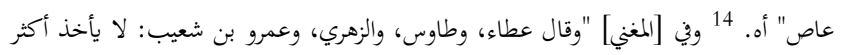

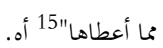

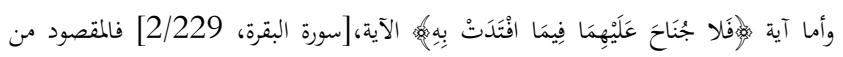

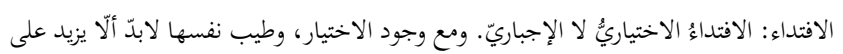

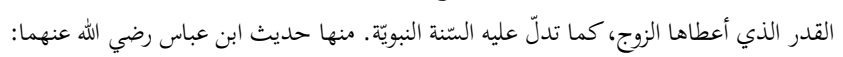

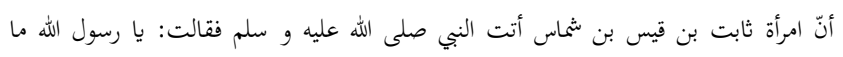

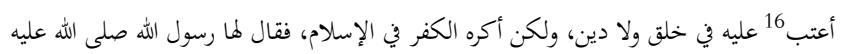

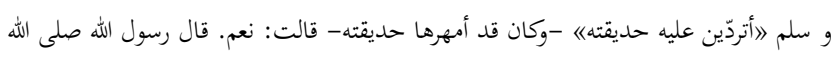

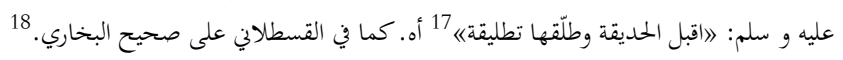
ومنها ما في "أحكام القرآن". عن ابن عباس أن رجلا خاصم امرأته إلى النبي صلى الله عليه

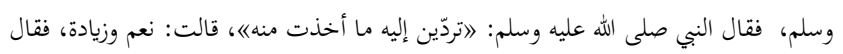

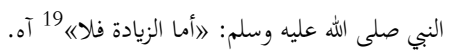

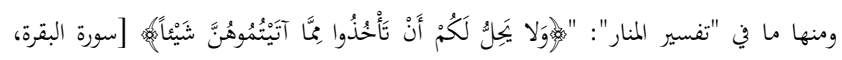

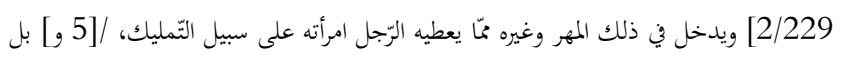

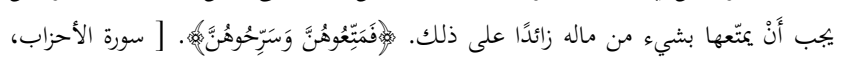

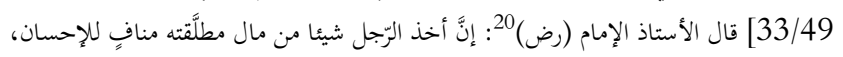

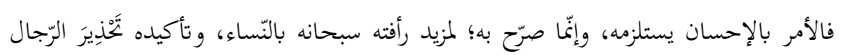

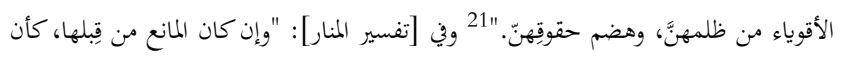

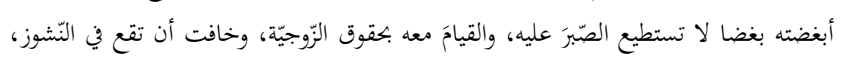

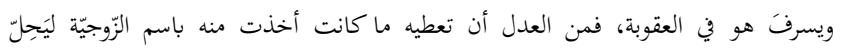

10 لفظ "قال" هنا وما يأتي بعده مكتوب بين القوسين. 11 الأم للشافعي، 295/5. 12 ما بين المعكوفتين ساقط من المخطوط، المثبت من أصل الكتاب المنقول منه. 13 13 ما بين المعكوفتين ساقط من المخطوط، المثبت من أصل الكتاب المنقول منه. 14 15 المغنى لابن قدامة، 269/10.

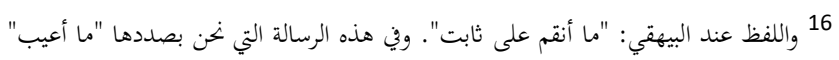

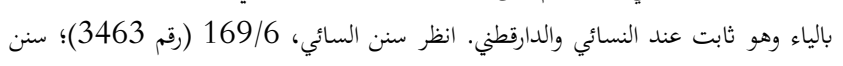
الدارقطني، 376/4 (رقم 3628).

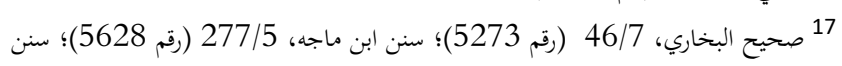

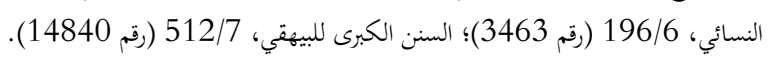

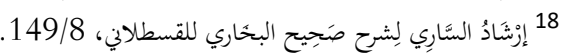

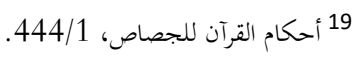
20 أي: رضي الله عنه.

21 تفسير المنار لمحمد رشيد رضا: 312/2 ألمعن

\section{تحقيق رسالة الحلع لا الظلم}

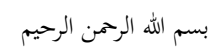

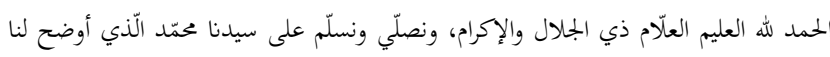

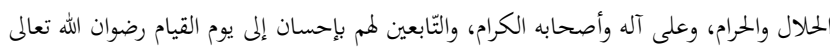

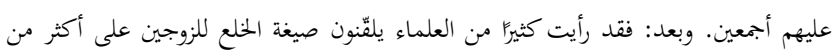

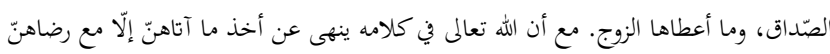

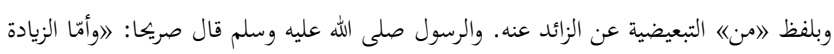

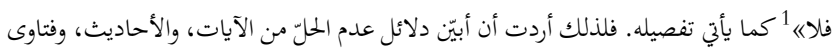

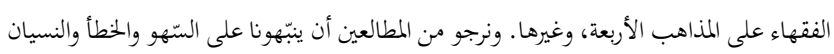

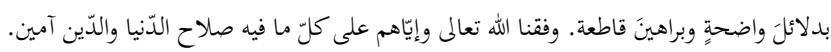

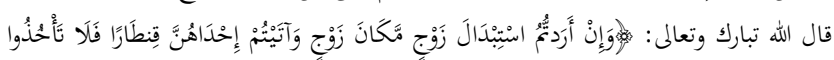

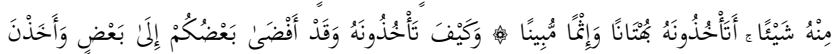

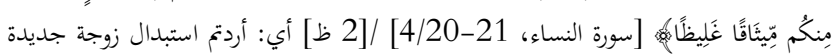

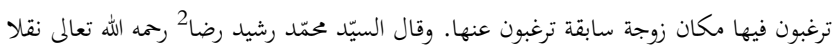

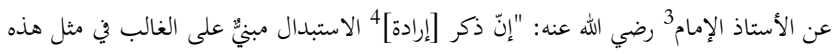

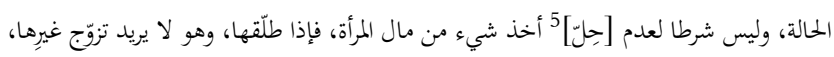

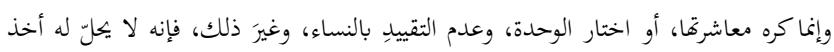

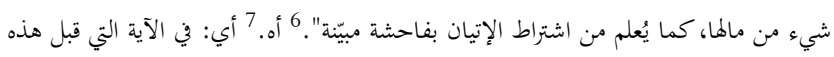

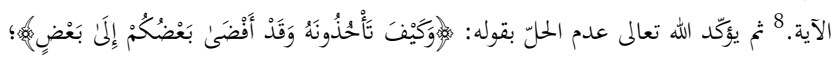

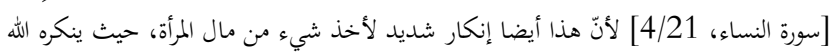

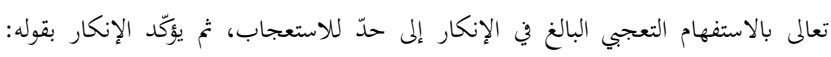

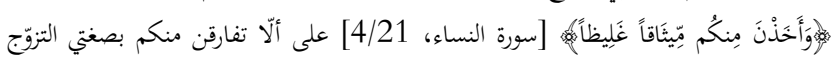

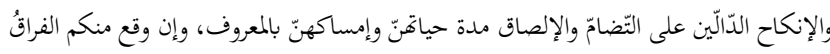

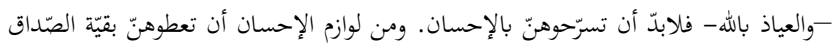

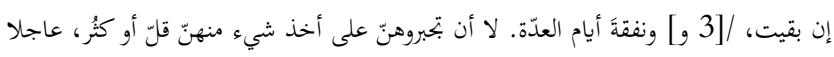

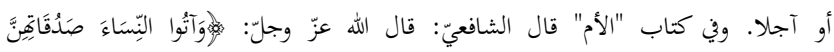

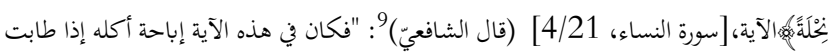

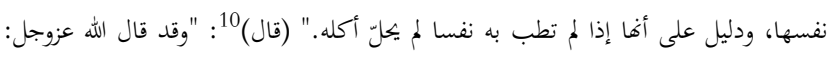

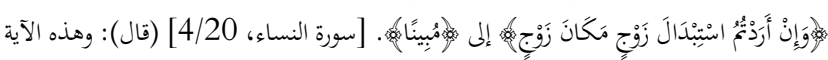

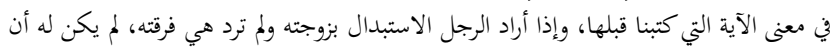

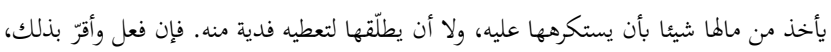

1 سنن الدارقطني، 376/4 (رقم 3628).

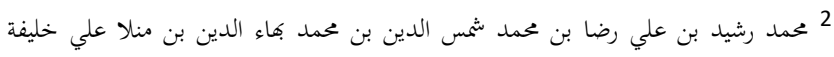

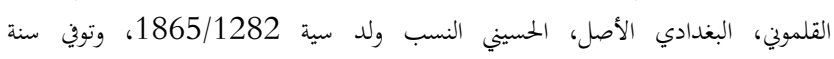
1935/1354 الأعلام للزركلي: 126/6. 3 وهو الشيخ محمد عبده بن حسن خير الله، مفتي الديار المصرية، ومن كبار رجال الإصلاح والتجديد في الإسلام، ولد سنة 1849/1226، وتوفي سنة 1905/1323. الأعلام للزركلي:

$.252 / 6$ 4 ما بين المعكوفتين ساقط من المخطوط، المثبت من أصل الكتاب المنقول منه.

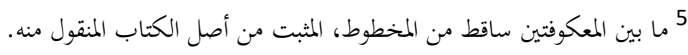

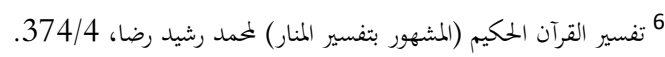
7

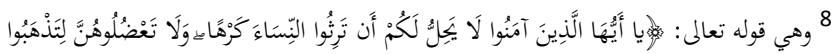

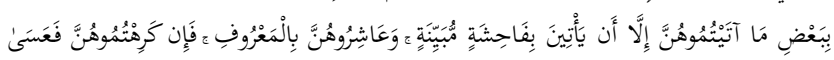

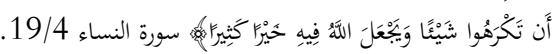

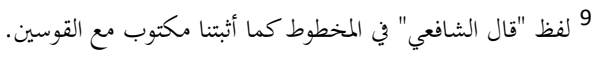




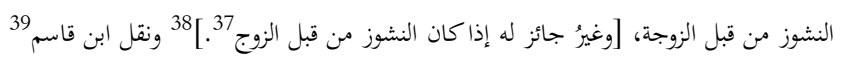

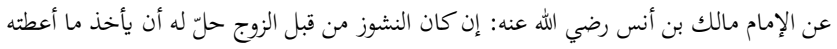

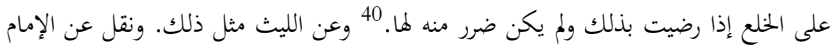

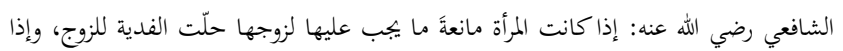

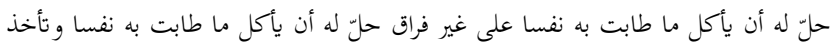

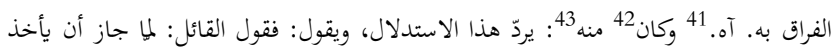

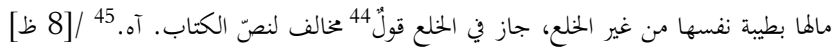

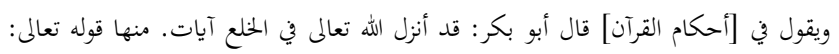

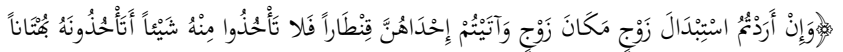

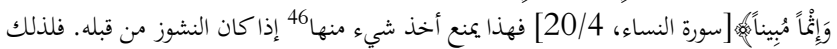

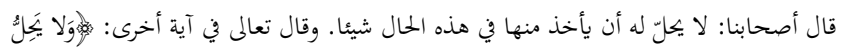

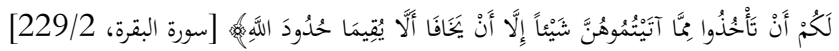

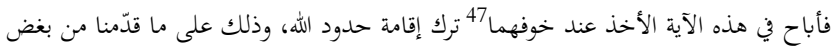

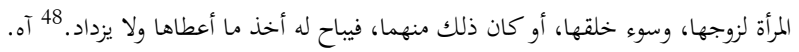

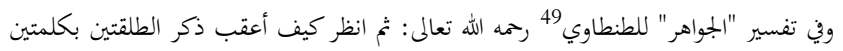

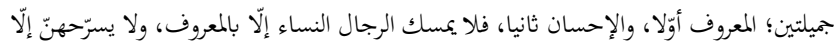

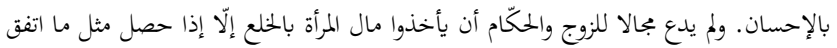

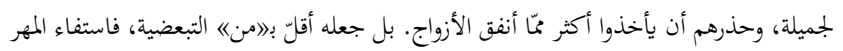

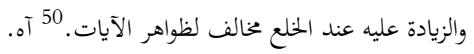

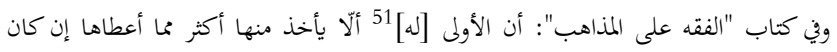

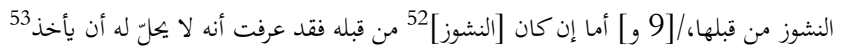

عُعقدًَا."22 وبعد أسطر يقول: "وجملة القول: أنه لا يجوز للرّجل أن يأخذ منها [شيئًا] 23 إلّا

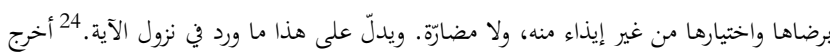

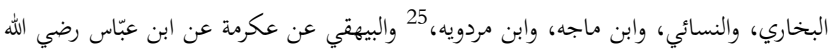

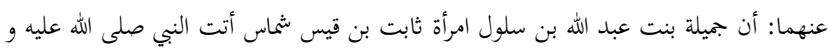

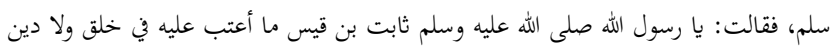

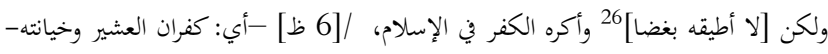

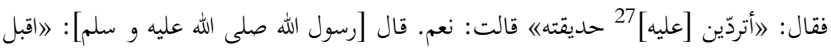

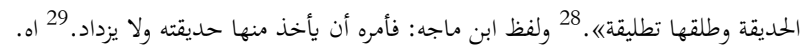

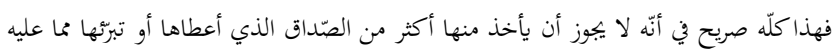

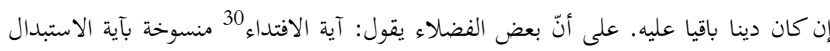

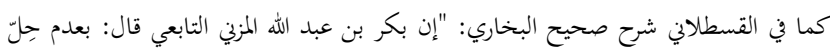

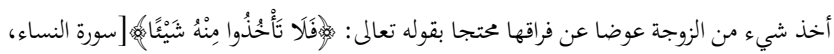

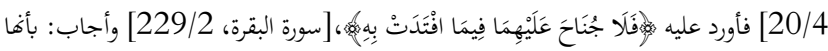

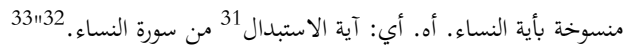

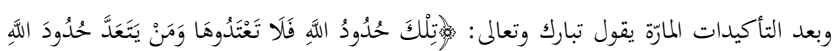

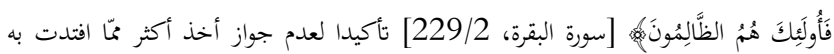

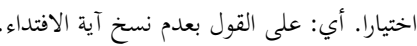

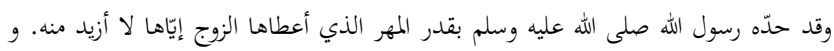

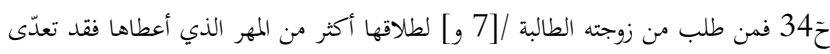
حدود الله، وهو من الظالمين (على لسان القرآن) 35 بأحكام الله تعالى.

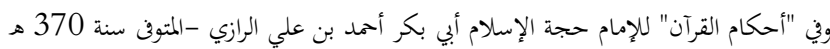

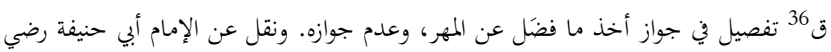

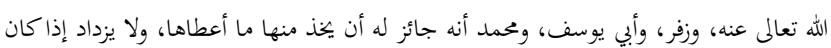

22 تفسير المنار لمحمد رشيد رضا: 313/2. في المخطوط "لَيحِلّ عقدها"، والمثبت من أصل الكتاب المنقول منه. 23 ما بين المعكوفتين ساقط من المخطوط، المثبت من أصل الكتاب المنقول منه.

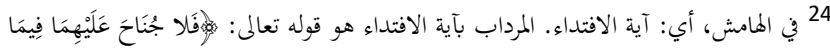

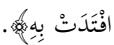

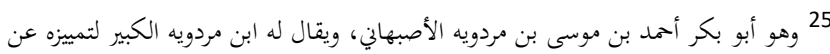

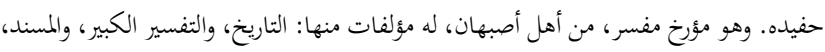

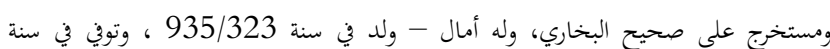

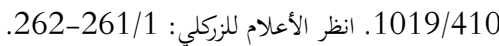

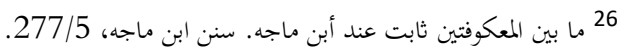
27

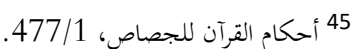
46 في المخطوط "منه" المثبت من أصل الكتاب المنقول منه. 47 في المخطوط "خوفها" المثبت من أصل الكتاب المنقول منه.

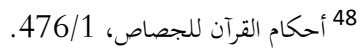

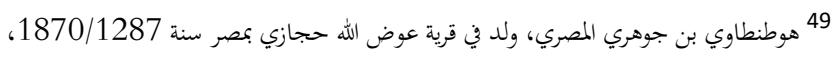

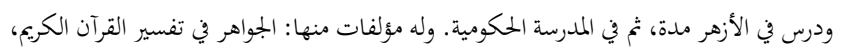

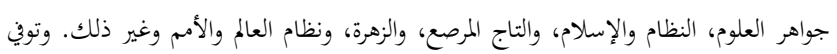
1940/1358. الأعلام للزركلي، 230/3. 50 الجواهر في تفسير القرآن الكريم للشيخ طنطاوي جوهري، 210/1 لإنلي، 51 ما بين المعكوفتين ساقط في المخطوط. والمثبت من الفقه على المذاهب الأربعة.

$$
52 \text { ما بين المعكوفتين غير ثابت في كتاب الفقه على المذاب الأربعة. }
$$$$
53 \text { في المخطوط "أخذ شيئ" المثبت من أصل الكتاب المنقول منه. }
$$

$$
28
$$

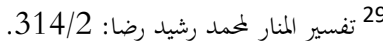
30

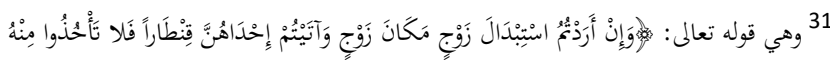

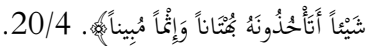
32 في الهامش: يدل على النسخ أنّ الثانية مدنية، والأولى مكية.

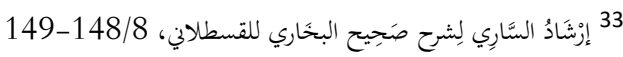
34

35 القوسان ثابت في المخطوط كما أثنتنا. 36 ترمز ب"ق" السنة القمرية.

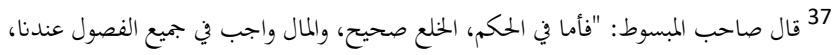

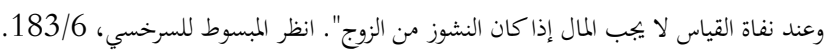


وفي "الفتاوى الكبرى" لشيخ الإسلام تقي الدين أبي العبّاس رحمه الله تعالى: الخلع الذي جاء به إلهاء

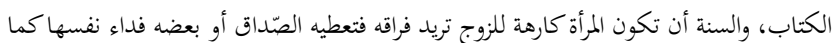

يفتدي الأسير إلخ.

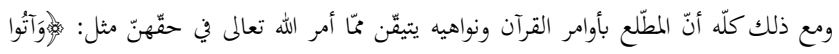

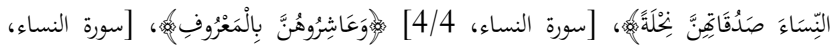

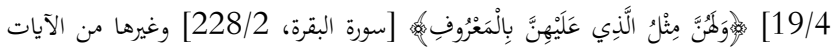

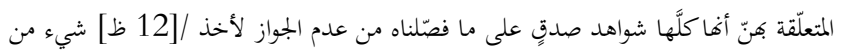

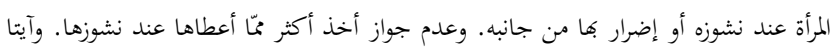

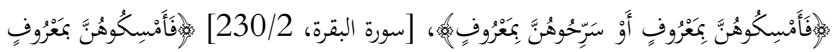

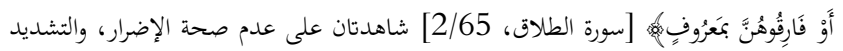

بالزوجة لتفتدي من نفسها.

[خلع الصغيرة]

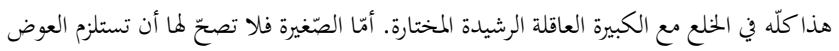

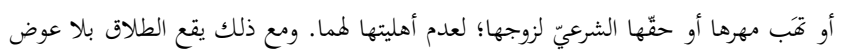

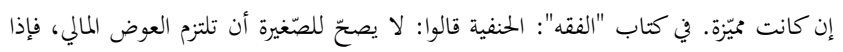

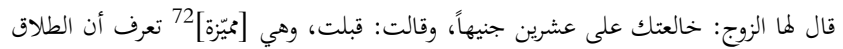

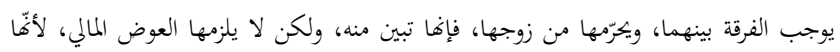

ليست أهلاً لالتزامه.

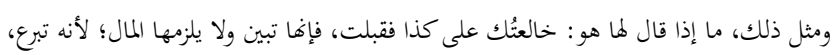

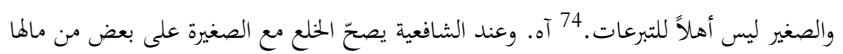

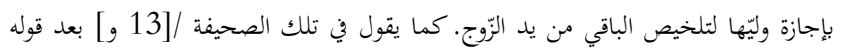

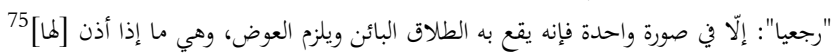

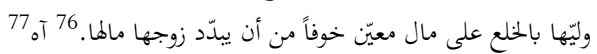

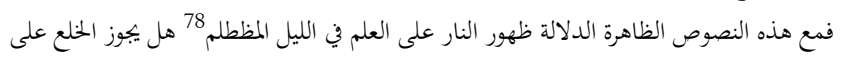

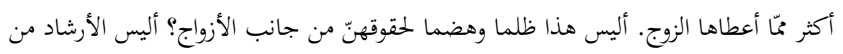

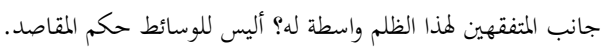

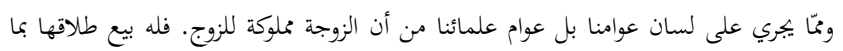

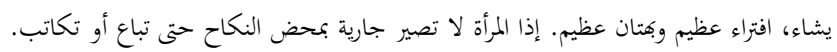

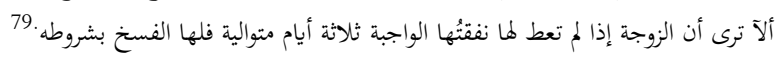

خاتمة
شيئًاً أبداً. 54 آه. هذا عند الحنفية. وأما عند الشافعي منه 55 نعم لا يحلّ للرجل أن يضارّ امرأته

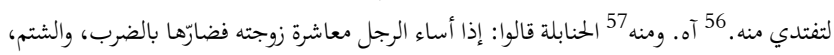

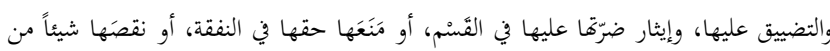

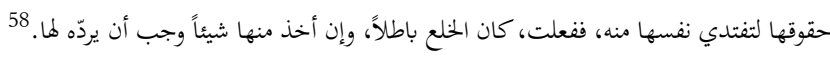

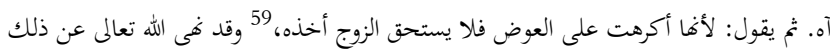

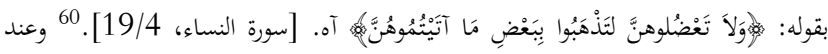

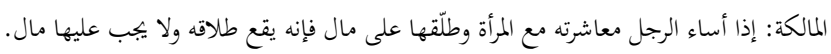

كما في "كتاب الفقه".

وفي تفسير "في ظلال القرآن": ولا يحلّ للرجل أن يسترد شيئا من صداق أو نفقة أنفقها في أثناء

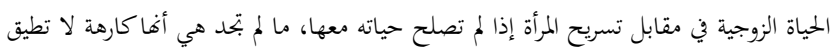

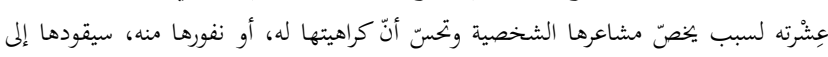

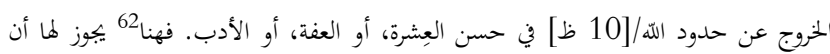

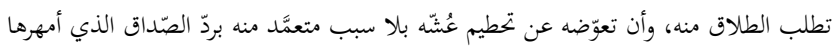

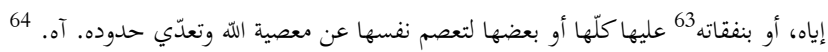

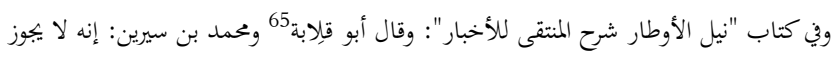

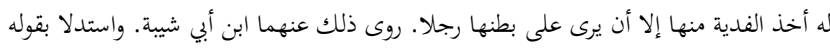

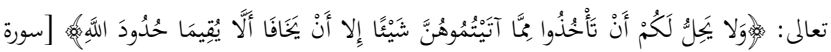

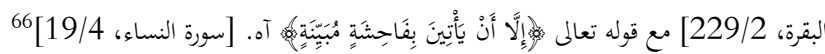

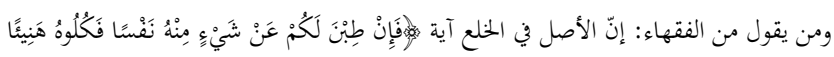

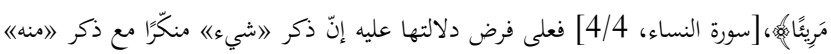

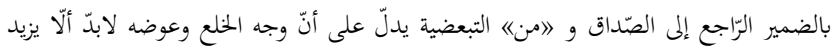

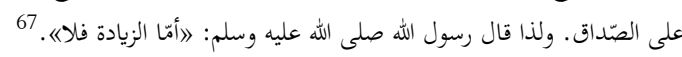

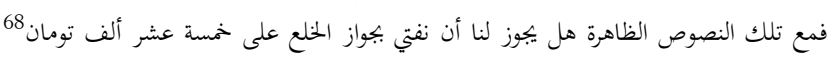

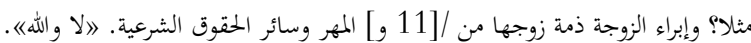

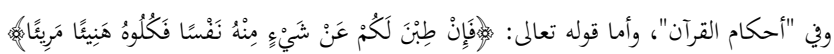

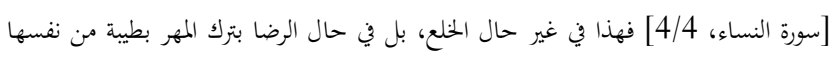

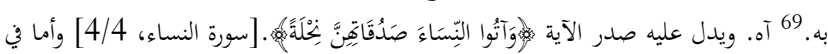

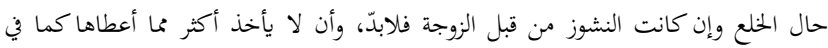

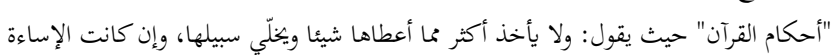
من قبلها.

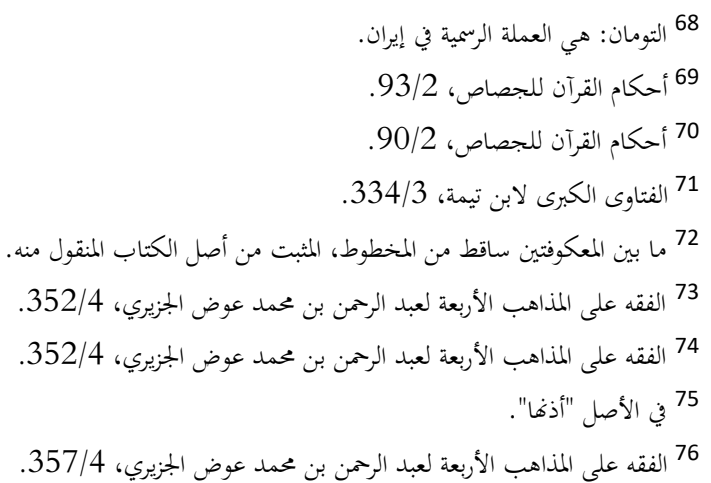

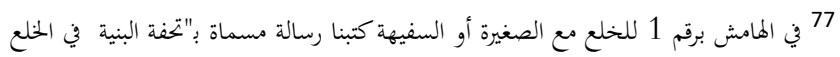

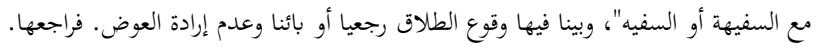

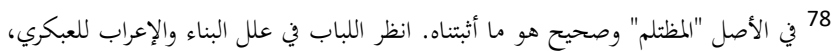

347-346/2
54 الفقه على المذاهب الأربعة لعبد الرحمن بن محمد عوض الجزيري، 345/4. 55 أي: من كتاب الفقه على المذاهب الأربعة.

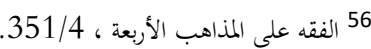
57 أي: من كتاب الفقه على المذاهب الأربعة.

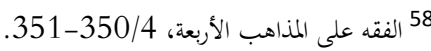
59 في المخطيط "أخذها". والمثبت من كتاب الفقه على المذاهب الأربعة.

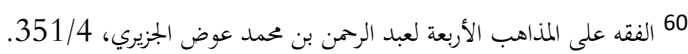

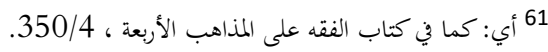

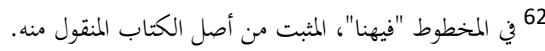
63 في المخطوط "بنفقاتا". والمثبت من في ظلال القرآن.

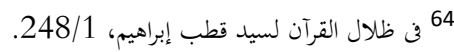

65 هو : عبد الله بن زيد بن عمرو الجرمي، تابعي من أهل البصرة، محدث عالم بالقضاء لقاء والأحكام. الأعلام للزركلي، 202/5. 66 نيل الأوطار للشوكاني، 294/6. 67 
الحقير محمد الخضري النرزيويى الأشنوي عفى عنه الملك الغفور القوىّ جلّ شأنه. 9 ذي الحجة

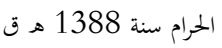

فبناء على ما فصّلناه يجب على القضاة والملقّنين/14 ظ] أن يجقّقوا النشوز الباعث للخلع هل

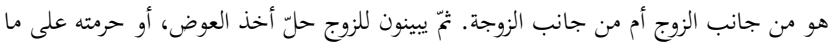

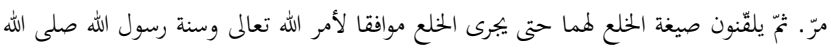
تعالى عليه وسلم.

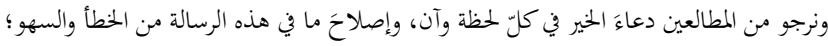

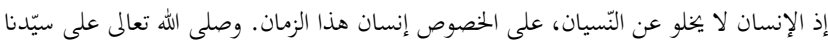

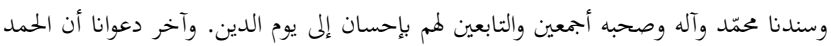
لله ربّ العالمين. 


\section{Extended Abstract}

Marriage, which constitutes the basis of family life, is an occasion for men and women to live together under certain conditions and by nikah. The most important phenomenon that enables men and women to find intimacy and tranquility in the world life and which contributes to the continuity of the human race is the marriage made by nikah. Marriage, which is based on love and respect, can sometimes leave its place to hatred and hostility. In a family where grudge and enmity are formed, the maintenance of marital life turns into an unbearable situation and the realization of what is aimed by marriage may become impossible. Islam has made it legitimate in various ways to terminate the nikah bond in order to prevent further wear and damage to the spouses when family life becomes insufferable. One of the types of divorce according to Islam is hul' / muhâle'a. If a woman cannot continue her marriage, Islam gives her the right to separate from her husband through hul', that is, in return for the woman paying a certain price to the husband and when the husband consents to this. This study consists of the tahqeeq and evaluation of the hukm of hul' and the price to be paid which are dealt with by Kadî Molla Muhammed el-Hıdırî in his risalah named al-Hul'u la az-zulmu and the biography of the writer. This study aims to present the issue of muhâle' $a$, which is an important issue in Islamic family law, to the relevant people and to introduce the Kadi Molla Muhammed alHidirî on the occasion of the aforementioned risalah.

What is essential in marriage is mutual love, respect and loyalty, forgiving the faults that may arise from both sides and the continuation of the marriage for a lifetime. For this reason, Islam rejects nikah contracts based on temporary union, such as Nikah Mut'ah, and defines nikahs made in this way as haram. Moreover, one of the indicators that the marriage desired by Islam is supposed to continue for perpetuity is that it in case of disagreement between the spouses it does not advise immediate divorce but recommends it as in three stages. The most important dalil of this is the following ayah of the Surah Al-Baqarah: "Divorce is twice. Then, either keep [her] in an acceptable manner or release [her] with good treatment ". The reason for this is to give chance to spouses in case they regret and want to live together again.

According to Islamic law, marriage can be terminated in many ways such as talaq, ila, li'an, faskh and tafreeq. Khul
/ mukhale'a, which expresses the separation of the spouses with mutual consent upon the woman's desire to leave her husband in return for paying a compensation in case of incompatibility, is one of the separation types that Islam deems legitimate. Islam does not find it appropriate to resort to a mukhale'a without conflict between the spouses. However, according to the majority of the fuqaha, the mukhale'a made even though there is no question of nushuz is considered valid legally. Therefore, it is possible to say the following: According to Islamic law, mukâle'a should be applied not on the basis of arbitrariness, but on a just cause such as incompatibility.

The issue of whether the muhâe'a made under pressure and threat will be considered valid has also been a matter of debate among scholars. The majority of the fuqaha did not consider it permissible for the husband to force his wife to the muhâe'a to take back the money he gave, and declared that the mukâle'a made under pressure was invalid and that the given property should be returned. Hanafi scholars stated that the contract made is sound and it is necessary to pay the price.

According to Islamic law, nushuz not resulting from the woman is not regarded as a justification for mukhale'a. According to the majority of the fuqaha, mukhale'a made under threat and pressure is also legally invalid.

Although Qadi Molla Muhammad Al Hidırî does not handle the subject of mukhale'a in his work Al Khul'u lâ ez-zulmu with all its details, he explains in which circumstances mukhale' $a$ is deemed sahih and caiz and in which conditions it is considered batil, the maximum amount of the compensation to be paid by the woman and whether the khul made for the nonadolescent girls is regarded jaiz or not, thoroughly. The muallif states that mukhale'a basically requires the mutual consent of the spouses that is mukhale'a made under threat and pressure is batil. Thus, the muallif adopts the view of the jumhur on this issue. He thinks that the khul compensation cannot be more than the mahr and claims that an amount exceeding the mahr means violation of the women's rights. He says that the mukhale'a made with the immature girls (nonadolescent) is not sahih but in case she is mumayyiz, talaq can be realized without compensation. 